\title{
Application of silicon nitride membrane filters in circulating tumor cell capture
}

- Van Vinh To

- Thi Phuong Tuyen Dao

- Van Binh Pham

- Duy Hien Tong

Laboratory for Nanotechnology, VNU - HCM

- Van Hieu Tran

University of Science, VNU - HCM

(Received on March $20^{\text {th }} 2013$, accepted on Jannuary $16^{\text {th }} 2015$ )

\begin{abstract}
Circulating tumor cells (CTCs) have been recognized as holding extraordinary potential for disease management in cancer patients including prognostic, therapy, and monitoring disease progression. Sensitive and quick detection of CTC could enable the approach to patients with early-stage and metastatic cancer. The technical challenge in this field consists of finding rare tumor cells (just a few CTCs in $1 \mathrm{ml}$ of blood) and being able to distinguish them from epithelial non-tumor cells and leukocytes. The current methodologies have significant limitations such as low capture efficiency, cannot capture live cells and time consuming. This paper presents the development of a new generation of microfilter for size-based isolation of CTCs in epithelial cancer using silicon nitride membrane filters $0.5 \mathrm{~cm}$ by 0.5 $\mathrm{cm}$ square sheets with slit shaped pores of $5 \mu \mathrm{m}$ by $15 \mu \mathrm{m}$. We evaluated the sensitivity and efficiency of CTCs capture in a model system using the MCF-7 cells (breast cancer cells) spiked in the blood from the healthy donors. Preliminary results this research shown that silicon nitride membrane filter is a very good candidate to be CTCs detection platfo.
\end{abstract}

Keywords: Microfilter, silicon nitride, circulating Tumor Cells, cancer

\section{INTRODUCTION}

Cancer is a leading cause of death worldwide and the most important determinant of prognosis and management of cancer is the absence or presence of metastasis [1-2]. The spread of tumor cells from primary tumors to peripheral blood is referred to as circulating tumor cells (CTCs) who can travel to distant organs through blood stream and form new tumors called metastases, those are responsible for the majority of cancer related deaths [3-4]. CTCs have attracted much recent interest in cancer research as a potential biomarker and as a means to study the process of metastasis. However the concept of circulating tumor cells is not a new one. It has long been understood that metastasis is a hallmark of malignancy by the "seed and soil" theory of 
metastasis formation, which predicted the existence of circulating tumor cells was first expounded in the late nineteenth century [5-7].

CTCs are recognized as holding extraordinary potential for disease management in cancer patients such as prognosis, therapy and monitoring of cancer. However, there are significant technical challenges in their isolation because CTCs exist in extreme rarity in blood even in patients with advanced disease. Indeed, CTCs are as few as 1 cell per 109 hematologic cells in the blood [8]. Several technologies are available to detect CTCs from whole human blood, ranging from density gradient centrifugation [9], micro-fluidic devices [8-11] and fast scanning flow cytometry [12] to commercially available technology based on the use of immunomagnetic beads [13,14]. However, these methodologies have significant limitations such as low capture efficiency ( $70 \%$ for density gradient centrifugation), labor intensive and subject to a large range of yield (9-90\%) due to variable expression of surface markers (for the technologies based on predominant existence on CTC surface of epithelial marker proteins such as epithelial cell adhesion molecule) [15].

Isolation of CTCs based on cell size using polycarbonate filters [16] and parylene-C membrane [17-18] have been demonstrated to be an efficient, inexpensive and user friendly way for enrichment of CTCs [16-19] by exploiting the fact that circulating epithelial tumor cells are significantly larger than the surrounding blood cells [16]. However these membrane filters have significant limitations such as large thickness (normally more than $10 \mu \mathrm{m}$ ) [17] which increase the transmembrane pressure and the time consumption resulting in the cell damage, low recovery rates and inefficiency of CTCs capture. Unlike classical technology, membrane filters fabricated with microfabrication techniques that used in semiconductor technology have several advantages in this application. The pores, the size-pores distribution and inter-pore distance can be precisely controlled by photolithographic methods and anisotropic etching. Filters with small thickness and smoothness pores have an extremely small flow resistance, which reduces processing time and filter fouling. With batch fabrication, this technology can be very cost effective, which makes it suitable to develop devices for routine test in the clinics.

In this study, we used silicon nitride ( $\mathrm{SiN})$ to fabricate the CTC capture filter. This material haves several properties, which make it a very good candidate for this application. As a high biocompatibility, bio fouling and cell rupture are expected to be minimal for SiN membrane. This is one of hardest materials known and is therefore well resistant against wear, which allows fabricating filters with very small thickness that supported by a rigid silicon support. The material is hydrophilic, inert to almost any chemical and can stand temperatures up to $800^{\circ} \mathrm{C}$. The membrane made from $\mathrm{SiN}$ is flat with a surface roughness smaller than $10 \mathrm{~nm}$. The combination of a very smooth surface and low transmembrane pressure makes the $\mathrm{SiN}$ membrane filters less sensitive to the fouling problems and suitable used in many filtration fields including yeast cell filtration of beer [20], leukocyte depletion from whole blood without activation of blood platelets [21], for hepatocyte sandwich culture [22], etc. However, the CTCs capture application of $\mathrm{SiN}$ membrane filter has not been available or found in the publications. In this study, we used the $\mathrm{SiN}$ membrane filter to evaluate the capacity of tumor 
cells capture by a model system using MCF-7 cells (breast cancer cells) spiked in the blood of free-cancer healthy donors. The purpose of study

\section{MATERIALS AND METHODS}

\section{Materials}

Calcein-AM and propidium iodide "Live/Dead Cell Double Staining Kit" was purchased from Sigma-Aldrich (Germany). The chemicals were purchased from MERCK (Singapore). MCF-7 cells were maintained and analyzed at Molecular Biotechnology Laboratory (University of Sciences, HCM city). The SiN membrane filters were generously provided by Nanosens Company (Berkelkade 11, 7201 JE, Zutphen, Netherlands) according to our design.

\section{Design of devices}

Design of filtration membrane is $0.5 \mathrm{~cm}$ by $0.5 \mathrm{~cm}$ square sheets using slit shaped pores that were formed by etching rectangular masks of 5 $\mu \mathrm{m}$ by $15 \mu \mathrm{m}$ with $10 \mu \mathrm{m}$ edge to edge distances. The membrane filters were fabricated by low stress silicon nitride that is deposited on two sides of a $<110>$ n-type double-sided polished is to develop a novel membrane microfilter for CTCs isolation based on size difference in blood of cancer patients.

silicon wafer by means of LPCVD (LowPressure Chemical Vapor Deposition).

\section{Membrane filter assembly}

Individual membrane filter was cut from the whole 4 inch wafer with dicing equipment (NDS 150, AM Technology) and sandwiched between two pieces of polydimethylsiloxane (PDMS) with wells to form a sealed chamber (Fig. 1). The fluidic accesses to the filter were provided from a $15 \mathrm{ml}$ conical tube containing the sample, which was connected to the constant pressure fluid delivery system as a reservoir. This system used pressure from a nitrogen tank which was downregulated accurately by adjusting a needle valve to 0.1 to 10 psi. Sample and washing buffer were collected in conical tube at the bottom chamber (Fig. 1).

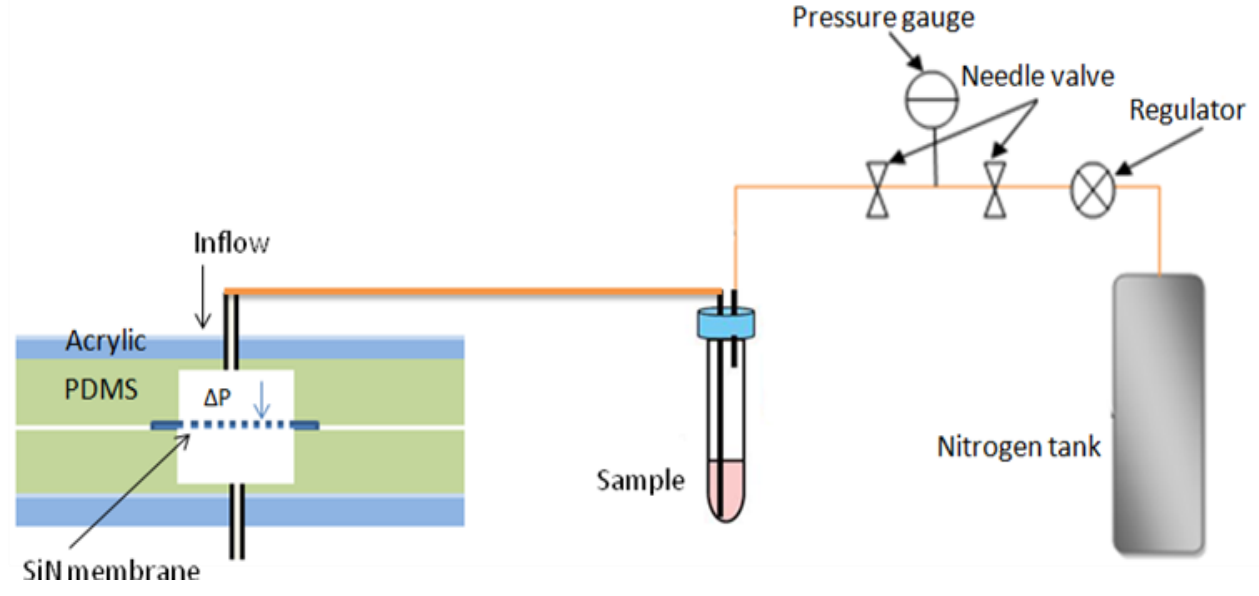

Fig. 1. Assembly of SiN membrane microfilers and constant pressure fluidic delivery system 


\section{Sample preparation}

Cultured MCF-7 cells derived from human metastatic breast carcinoma were grown in DMEM medium, supplemented with $10 \%$ FCS (Sigma-Aldrich) in a $75 \mathrm{~cm}^{2}$ or $25 \mathrm{~cm}^{2}$ tissue culture flask (Corning) and maintained in a humidified incubator at $5 \% \mathrm{CO} 2$ and $37^{\circ} \mathrm{C}$. Tumor cells were counted manually on hemacytometers. Cell viability was measured using a dye exclusion method (Invitrogen Corp.) where for each experiment; the cell viability showed $\geq 90 \%$ healthy cells after detachment from culture flask and washing steps. The tumor cells were stained with The "Live/Dead Cell Double Staining Kit" (Sigma-Aldrich), which is utilized for simultaneous fluorescence staining of viable and dead cells. This kit contains calceinAM and propidium iodide (PI) solutions, which stain viable and dead cells, respectively. The stained cells were serially diluted in phosphate buffered saline (PBS) to the desired concentration for device testing. For recovery testing, the cells were diluted to between 10 and $10^{3}$ cells $/ \mathrm{ml}$ to minimize dilution and counting errors the cell counts were repeated 10 times. Blood samples were drawn from the free-cancer healthy donors into EDTA tubes and processed within 24 hours.

\section{Flow rate characteristics}

To provide constant pressure source at the inlet of the microdevice, pressure regulators were connected in series from a nitrogen tank to a working range of 0.1 to $10 \mathrm{psi}$. A pressure meter was connected near the inlet of the device to monitor the pressure source. For each measurement, sample solution was first injected into an inlet reservoir with the 1 psi pressure source in the "closed" position. Upon opening the valve to the pressure source, the time and flow rate were recorded where the flow rate was monitored through mass change in the collection tube.

\section{Recovery rate measurements}

It is very difficult to detect the CTCs in the blood of cancer patient; therefore we simplified the recovery rate measurements by mixing of tumor cells in to diluted blood from healthy donors as a model system in order to mimic real samples. To measure the ability of microfilter to capture selectively the tumor cells from blood cells, stained cultured tumor cells (MCF-7) were serially diluted to the desired number and were spiked in to diluted blood. The sample was dispensed through the filter from a reservoir with constant pressure and the filter containing captured cells was washed with PBS to discard debris from filter surface. Tumor cells were identified and distinguished from blood cellsbased on morphology and staining of fluorescent dyes. Tumor cells were counted manually and imaged directly on filter membranes placed onto microscope slides using a fluorescent microscope and CCD camera (BX41, Olympus)

\section{RESULTS}

\section{Device fabrication and characterization}

Microfabricated SiN membrane filters were characterized by scan electron microscopy (SEM). The SEM images showed a smooth surface membrane with the uniformly shaped pores and a narrow pore-size distribution (Fig. 2A, 2B). The uniform pore size distribution is one of the most important features, which makes the membrane filter suitable for the application in cell to cell separation based on size difference. 
The slit shaped pores were used in order to maximize cellular deformation and passage of blood cells in the longitudinal axis while capture lager and less deformable cells (cancer cells). The slit design generated a large fill factor, thus reducing the flow resistance and filtration pressure. The pore size is $5 \mu \mathrm{m}$ by $15 \mu \mathrm{m}$, interrow distance is $10 \mu \mathrm{m}$ and inter-pore distance is 5 $\mu \mathrm{m}$ (Fig. 2B).

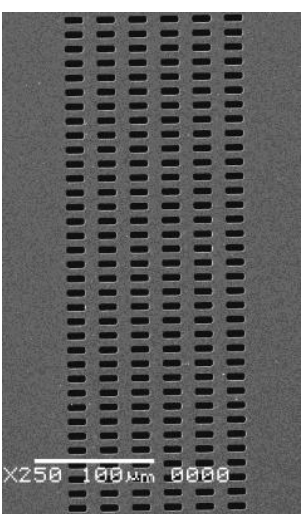

(A)

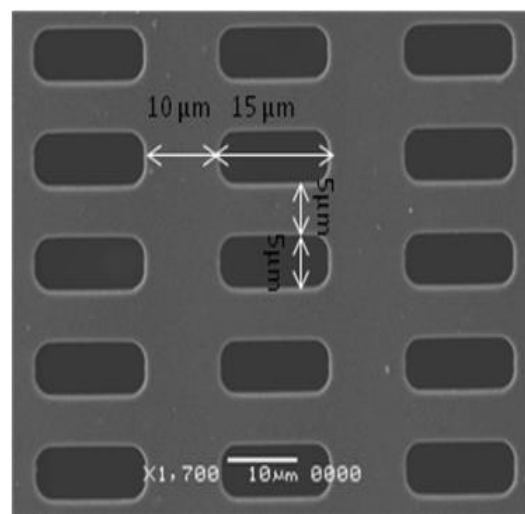

(B)

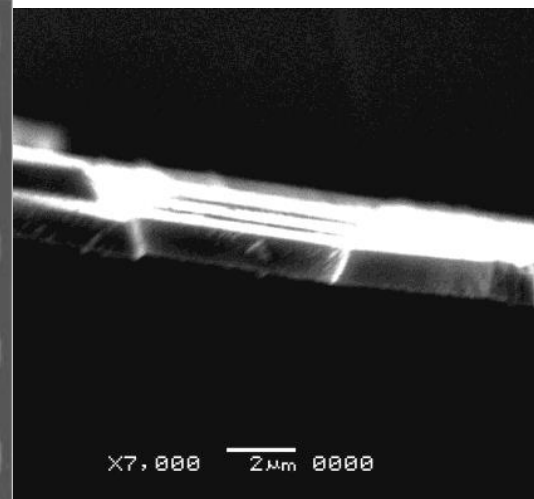

(C)

Fig. 2. Characterization of porous SiN membrane by scanning electron microscopy (SEM): (A), SEM micrograph of high porosity membrane; (B), SEM micrograph of porous membrane at high magnification showing the slit pores of $5 \mu \mathrm{m}$ by $15 \mu \mathrm{m}$ size; (C), SEM micrograph at high magnification showing the thickness of porous $\mathrm{SiN}$ membrane corresponding $1 \mu \mathrm{m}$.

The porosity is calculated by dividing the porous area by the whole area of the membrane is corresponding to approximately $25 \%$ in working area.The thickness of membrane is approximately $1 \mu \mathrm{m}$ thick (Fig. 2C). This small thickness makes the filters insensitive to fouling and resulting very low filtration pressures, critical for preserving the morphology and viability of live CTCs.The mechanical properties of $\mathrm{SiN}$ membrane filters were also characterized such as the resistance of membrane filters to pressure and chemically resist corrosion.

The assembly of microfilters was constructed by sandwiching individual membrane filters with two plates of polydimethylsiloxane (PDMS) and clamped by acrylic jigs to form sealed fluidic chambers as showed in Fig. 2. The pressure difference caused by the nitrogen tank between top chamber and bottom chamber will push the sample traverse through the membrane filter. 


\section{Flow rate characteristics using the different samples}

To monitor the flow rate characteristics, we used various samples, including phosphate saline puffer (PBS), CTCs in PBS (103 cells $/ \mathrm{ml}$ ), diluted blood in PBS (10\%) and blood sample (100\%) using a constant pressure (1 psi). Paraformaldehyde (PFA) a formaldehyde-based fixative, which forms methylene cross-links between basic amino acids, was used to preserve the cell morphology.

The samples were fixed with or without PFA (2 $\%$ or $0 \%$ ) to measure the effect of composition of sample and cell fixation on flow rate through the microfilters. The flow rate was monitored by indirectly measuring the weight of the flow- through liquid in relation to time. Flow rate under constant pressure (1 psi) of samples with different compositions and with or without fixative PFA (listed above) were measured and plotted in Fig. 3. Results demonstrated that the most important determinant of flow rate is the composition of the fluidic components in the sample including the concentration of blood cells. The presence of blood cells (10\% and 100 $\%)$ quickly decreased the flow rate and even clogged the filters because very large leukocytes and rouleaux of erythrocytes can be captured on the microfilters. To diminish that problem the treatment of blood sample may be required to avoid activation of blood platelets that form agglomerates of erythrocytes.

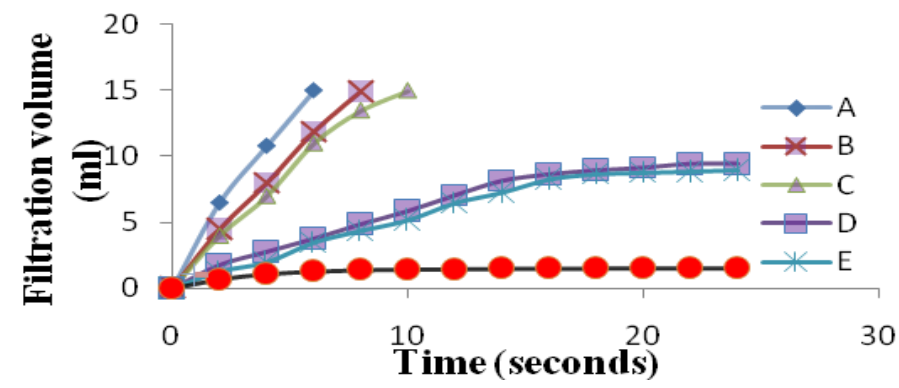

Fig. 3. Flow rate characteristics of the membrane filters with various samples under constant pressure of 1 psi. A, only PBS; B, PBS with $10^{3}$ tumor cells MCF-7/ml; C, PBS with $10^{3}$ tumor cells MCF-7/ml fixed in $2 \%$ PFA; D, 10 $\%$ blood in PBS; E, $10 \%$ blood PBS fixed in $2 \%$ PFA; F, $100 \%$ blood from the healthy donors.

\section{Recovery rates tumor cells}

In order to evaluate the capacity of CTCs capture by monitoring the recovery rate of the membrane filters, Tumor cells-MCF-7 were stained with calcein-AM and propidium iodide (PI), which stain viable and dead cells, respectively. Calcein-AM is a non-fluorescent, hydrophobic compound that easily permeates intact, live cells. The hydrolysis of Calcein-AM by intracellular esterases produces calcein, a hydrophilic, strongly fluorescent compound that is well-retained in the cell cytoplasm and stains cells as green. PI is membrane impermeant and generally excluded from viable cells. Therefore PI is used for identifying dead cells in a population by binding to DNA and ARN that stains cells as red. The stained cells were serially diluted to desired concentration and dispensed through the membrane filter followed by rinsing 
twice with PBS. The volume of filtration samples is $1 \mathrm{ml}$ with various concentrations ranging from 10 cells $/ \mathrm{ml}$ to 103 cells $/ \mathrm{ml}$. Each measurement was repeats three times. Table 1 summarizes the recovery rates for both series of non-fixed samples and fixed samples with $2 \%$ PFA. The results demonstrated a significantly higher recovery rate by cell fixation with PFA corresponding to $94 \%$ against $82.6 \%$.

We tested whether our microfilter device can isolate tumor cells from blood cells by spiking the stained MCF-7 cells with known numbers in to diluted blood (10\% blood in PBS) that was collected from healthy donors. We used the diluted blood because it allows mimicking the real clinical samples with all cellularity of blood but with lower concentration of blood cells, which facilitates the filtration process. Each measurement, 10 stained tumor cells were spiked in to $10 \mathrm{ml}$ diluted blood (10\% blood in PBS) from healthy donors with observation under microscope. A total 20 replicates was done, in which the microfilter was able to detect $\geq 1$ tumor cell in 15 of 20 replicates. We also controlled negative sample from 2 healthy individuals and none of the samples from healthy volunteers had any detection.

Table 1. Recovery rate test of microfilter using MCF-7 cells in PBS with different concentrations PFA-fixed or free fixation. The volume of sample is $1 \mathrm{ml}$

\begin{tabular}{c|ll|ll}
\hline \multirow{2}{*}{ Test number } & Non-fixed & Fixed with 2\% PFA & \\
\cline { 2 - 5 } & $\begin{array}{l}\text { Concentrations } \\
\text { cells/ml) }\end{array}$ & Cells recovered & Concentration (cells/ml) & Cells recovered \\
\hline 1 & 10 & 9 & 10 & 9 \\
2 & 10 & 7 & 10 & 11 \\
3 & 10 & 8 & 10 & 8 \\
4 & 100 & 82 & 100 & 95 \\
5 & 100 & 85 & 100 & 98 \\
6 & 100 & 79 & 100 & 89 \\
7 & 1000 & 891 & 1000 & 986 \\
8 & 1000 & 823 & 1000 & 927 \\
9 & 1000 & 861 & 1000 & 931 \\
\hline $\begin{array}{l}\text { Average of } \\
\text { recovery rates (\%) }\end{array}$ & & $\mathbf{8 2 . 6 \%}$ & $\mathbf{9 4 \%}$ \\
\hline
\end{tabular}

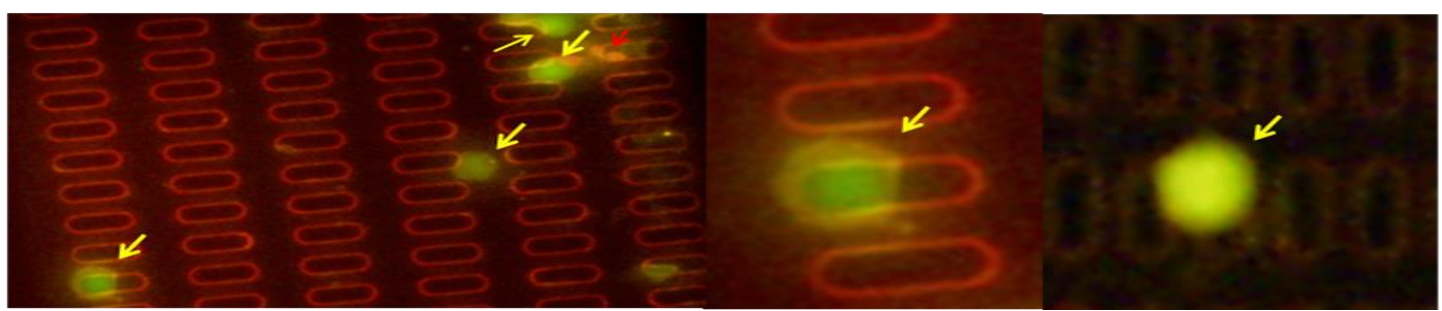

Fig. 4. Fluorescent microscopic images of tumor cell captured onto the SiN membrane filter. The tumor cells was stained by fluorescent calcein-AM and PI dye flowing by a cell fixation with $2 \%$ PFA for 10 min, imaged manually by fluorescent microscope (BX41, Olympus). 


\section{DISCUSSION}

The detection of rare human CTCs is a clinically relevant event in the blood of cancer patients. Isolation of CTCs based on cell size using microfilters has been demonstrated to be an efficient, inexpensive and user-friendly method $[16,18,24]$. However, there are technical challenges in building a microfilter device for CTCs isolation. The detection sensitivity required is high, with ability to capture as few as one CTC in $7.5 \mathrm{~mL}$ of whole blood, which contains about 10 billion blood cells. The sample volume required to be processed is in the milliliter range, while microdevices are normally used to process microliter or even nanoliter volumes of sample. Such a challenge is further exacerbated when dilution of blood is required. And the membrane fouling is one of the most important problems in crossflow filtration especially when process with the blood samples. In this report, we shown a possible solution using an advanced $\mathrm{SiN}$ membrane filter, which is perfectly in accord with the requirements described above. Microfabricated SiN membrane filter has a small thickness (1 $\mu \mathrm{m})$ and high porosity (approximately $27 \%$ in working area) that are the most important features determining the resistance of a membrane. Indeed, our microfilter device provides a capacity of filtration with superior flow rates in comparison with the classical membrane filters [17, 18, 24] even using a small transmembrane pressure. While the CTCs detection sensitivity can be achieve by well defined pore size and uniform pore size distribution that is easily controllable by photolithographic method and anisotropic etching, which was used in our SiN membrane fabrication. SiN membrane filter was characterized by SEM images and shown that it is suitable for CTCs capture application.

The average diameter of erythrocytes (RBCs) is in range of 5-9 $\mu \mathrm{m}$ [25] but they can traverse capillaries of $4 \mu \mathrm{m}$ due to their deformability [26]. Early study on filtration of normal human red blood cells (RBC) concludes that their transmission can achieve $100 \%$ for pore size larger than $3.3 \mu \mathrm{m}$ [10]. Morphometric analyses of mean whole cell areas of tumor cell and leukocytes show a significant difference. The mean tumor cell/leukocyte area ratio was 5.7 for Hep3B, 4.5 for Hep3B (derived from human hepatocellular carcinomas), 4.1 for $\mathrm{LNCaP}$ (derived from human prostatic adenocarcinoma) and 2.8 for MCF-7 (derived from human breast adenocarcinoma) [16]. The size difference between CTCs and blood cells enable the using of microfilter for CTCs separation from the normal blood cells. In this study, we used MCF-7 (breast cancer cell line) with average of whole cell area of $396 \mu \mathrm{m}^{2}$ [16] to evaluate the recovery rate of microfilters. It is one of small cancer cell lines, which make it suitable to test a high capacity of microfilters for cancer cells capture. $\mathrm{SiN}$ membrane filter is capable to capture $82 \%$ MCF-7 cells with non-fixed samples and 94\% with fixed samples; it can achieve higher recovery rates with the bigger cancer cells.

The tumor cell detection was confirmed with more than one cell in 15 of 20 replicates (75\%). It is not a very high recovery rate in comparison with other CTCs detection platforms. In addition, the used sample was not whole blood and with a small volume $(10 \mathrm{ml}$ corresponding to $1 \mathrm{ml}$ whole blood). However the most important issue is that the microfilter is able to capture 
selectively the tumor cells from blood cells. Further applications in CTCs capture in cancer patient's blood can absolutely be performed because the recovery rate can be improved by optimizing the filter's features and filtration process. This is our first design of membrane filter for this application and the CTCs detection is never easy of approach. Indeed, we are testing for many designs, and optimizing filtration and sample treatment process to obtain an ideal microfilter device for CTCs detection in peripheral blood of cancer patients.

\section{CONCLUSION}

SiN membrane filter was successfully fabricated by microfabrication techniques using photolithographic methods and anisotropic etching. The SEM characterization of fabricated porous membrane demonstrated it is a good candidate for CTCs detection application. We also fabricated a constant-pressure fluid delivery system and filter holders, which suitable to assemble a whole microfilter device for cancer cells separation from blood cells. Results of experiments for recovery rates and cancer cells capture sensitivity make our device to be a potential platform for CTCs detection in blood of cancer patients.

\section{ACKNOWLEDGMENTS}

This research is partial of the project "Study on fabrication of silicon nitride micromfilter for detecting circulating tumor cells in breast cancer" that was supported by grants from Vietnam National University Ho Chi Minh City. We also thank Nanosens Company (Berkelkade 11, 7201 JE, Zutphen, Netherlands) for providing the SiN microfilter.

\section{Ưng dụng của màng lọc Silicon nitride trong việc bắt giữ tể bào ung thư tuần hoàn}

- Van Vinh To

- Thi Phuong Tuyen Dao

- Van Binh Pham

- Duy Hieu Tong

Phòng Thí nghiệm Công nghệ Nano, ĐHQG - HCM

- Van Hieu Tran

Trường Đại học Khoa học Tự nhiên, ĐHQG-HCM

\section{TÓM TÁT}

Tế bào ung thư tuần hoàn (CTCs) đã được công nhận như một công cụ tiềm năng trong việc quản lý những bệnh nhân ung thư như tiên lượng, điều trị và theo dõi tiến triển của bệnh. Sự phát hiện nhanh và nhạy CTCs có thể cho phép tiếp cận với bệnh nhân ung thư ở giai đoạn đầu và di căn. Tuy nhiên, vẫn còn những thách thức kỹ thuật trong lĩnh vực này như việc tìm kiếm các tế bào ung thư (chỉ là một vài CTCs trong $1 \mathrm{ml}$ máu), phân biệt 
với các tế bào không ung thư và bạch cầu biểu mô. Các phương pháp hiện nay có những hạn chế đáng kể như hiệu quả bắt giữ thấp, không thể bắt giữ các tế bào sống và tốn nhiều thời gian. Báo cáo này trình bày sự phát triển của một bộ lọc micro thế hệ mới để phân lập CTCs dựa vào kích thước của chúng trong ung thư biểu mô. Chúng tôi đã sử dụng các bộ lọc màng silicon nitride có kích thước $0,5 \mathrm{~cm}^{*} 0,5 \mathrm{~cm}$ với kích thước lỗ lọc hình chữ nhật là $5 \mu m * 15 \mu m$ để khảo sát

Từ khóa: Màng lọc micro, silicon nitride, tế bào ung thư tuần hoàn, ung thư hiện CTCs.

\section{REFERENCES}

[1]. A. Jemal, R. Siegel, E. Ward, Y. Hao, J. Xu, T. Murray, M.J. Thun, Cancer statistics, $C A$ Cancer J Clin, 58, 71-96 (2008).

[2]. T.G. Lugo, S. Braun, R.J. Cote, K. Pantel, V. Rusch, Detection and measurement of occult disease for the prognosis of solid tumors, Journal of Clinical Oncology, 21, 13, 2609-2615 (2003).

[3]. C. Wittekind, M. Neid, Cancer Invasion and Metastasis, Oncology, 69 (Suppl. 1) 14-16 (2005).

[4]. L. Weiss, Metastasis of cancer: a conceptual history from antiquity to the 1990s, Cancer Metastasis Rev, 19(I-XI) 193-383 (2000).

[5]. D. Hanahan, R.A. Weinberg, Hallmarks of cancer: the next generation, Cell, 144, 5, 646 (2011).

[6]. M. Alunni-Fabbroni, M.T. Sandri, Circulating tumour cells in clinical practice: Methods of detection and possible characterization, Methods, 50, 289-297 (2010).

[7]. S. Paget, The distribution of secondary growths in cancer of the breast, Lancet, 133, 3421, 571-573 (1889). việc bắt giữ CTCs. Độ nhạy và hiệu quả của việc bắt giữ $\mathrm{CTCs}$ được đánh giá trong một hệ thống mô hình bằng cách sử dụng các tế bào MCF - 7 (các tế bào ung thư vú) cho vào máu (máu được lấy từ những người khỏe không bị ung thư) rồi lọc và bắt giữ tế bào MCF-7. Kết quả sơ bộ của nghiên cứu này cho thấy màng lọc silicon nitride là một ứng cử viên rất tốt để làm nền tảng cho việc phát

[8]. S. Nagrath, L.V. Sequist, S. Maheswaran, D.W. Bell, D. Irimia, L. Ulkus, M.R. Smith, E.L. Kwak, S. Digumarthy, A. Muzikansky, P. Ryan, U.J. Balis, R.G. Tompkins, D.A. Haber, M. Toner, Isolation of rare circulating tumour cells in cancer patients by microchip technology, Nature, 450, 20, 1235 -1239 (2007).

[9]. K. Pantel, R.H. Brakenhoff, Dissecting the metastatic cascade, Nat. Rev. Cancer, 4, 448 (2004).

[10]. S. Chien, S. Usami, R. Dellenba, M. Gregerse, Shear-dependent deformation of erythrocytes in rheology of human blood, Am J Physiol, 219, 136-142 (1970).

[11]. S.L. Stott, C.H. Hsu, D.I. Tsukrov, M. Yu, D.T. Miyamoto, B.A. Waltman, S.M. Rothenberg, A.M. Shah, M.E. Smas, G.K. Korir, F.P. Floyd, A.J. Gilman, J.B. Lord, D. Winokur, S. Springer, D. Irimia, S. Nagrath, L.V. Sequist, R.J. Lee, K.J. Isselbacher, S. Maheswaran, D.A. Haber, M. Toner, Isolation of circulating tumor cells using a microvortex-generating herringbone-chip, 
Proc Natl Acad Sci USA, 107, 43, 18392 (2010)

[12]. R.T. Krivacic, A. Ladanyi, D.N. Curry, H.B. Hsieh, P. Kuhn, D.E. Bergsrud, J.F. Kepros, T. Barbera, M.Y. Ho, L.B. Chen, R.A. Lerner, R.H. Bruce, A rare-cell detector for cancer, Proc Natl Acad Sci USA, 101, 1050110504 (2004).

[13]. A.H. Talasaz, A.A. Powell, D.E. Huber, J.G. Berbee, K.H. Roh, W. Yu, W. Xiao, M.M. Davis, R.F. Pease, M.N. Mindrinos, S.S. Jeffrey, R.W. Davis, Isolating highly enriched populations of circulating epithelial cells and other rare cells from blood using a magnetic sweeper device, Proc Natl Acad Sci USA, 106, 3970 (2009).

[14]. T. Fehm, A. Sagalowsky, E. Clifford, P. Beitsch, H. Saboorian, D. Euhus, S. Meng, L. Morrison, T. Tucker, N. Lane, B.M Ghadimi, K. Heselmeyer-Haddad, T. Ried, C. Rao, J. Uhr, Cytogenetic evidence that circulating epithelial cells in patients with carcinoma are malignant, Clin Cancer Res, 8, 7, 207 (2002).

[15]. O. Lara O, X.D. Tong, M. Zborowski, J.J. Chalmers, Enrichment of rare cancer cells through depletion of normal cells using density and flow-through, immunomagnetic cell separation, Exp Hematol, 32, 891-904 (2004).

[16]. G. Vona, A. Sabile, M. Louha, V. Sitruk, S. Romana, K. Schutze, F. Capron, D. Franco, M. Pazzagli, M. Vekemans, B. Lacour, C. Brechot, P. Paterlini-Brechot, Isolation by size of epithelial tumor cells : a new method for the immunomorphological and molecular characterization of circulatingtumor cells, Am. J. Pathol, 156, 1, 57-63 (2000).
[17]. S. Zheng, H. Lin, J.Q. Liu, M. Balic, R. Datar, R.J. Cote, Y.C. Tai, Membrane microfilter device for selective capture, electrolysis and genomic analysis of human circulating tumor cells, J. Chromatogr. A, 1162, 154 (2007)

[18]. H.K. Lin, S. Zheng, A.J. Williams, M. Balic, S. Groshen, H.I. Scher, M. Fleisher, W. Stadler, R.H. Datar, Y-C. Tai, R.J. Cote, Portable filter-based microdevice for detection and characterization of circulating tumor cells, Clinical Cancer Research, 16, 5011 (2010).

[19]. G. Vona, C. Beroud, A. Benachi, A. Quenette, J.P. Bonnefont, S. Romana, A. Munnich, M. Vekemans, Y. Dumez, B. Lacour, P. Paterlini-Brechot, Enrichment, immunomorphological, and genetic characterization of fetal cells circulating in maternal blood, Am. J. Pathol, 160, 51 (2002).

[20]. G. Vona, L. Estepa, C. Beroud, D. Damotte, F. Capron, B. Nalpas, A. Mineur, D. Franco, B. Lacour, S. Pol, C. Brechot, P. Paterlini-Brechot, Impact of cytomorphological detection of circulating tumor cells in patients with liver cancer, Hepatology, 39, 792 (2004).

[21]. C.J.M. van Rijn, W. Nijdam, L.A.V.G. van der Stappen, O.J.A. Raspe, L. Broens, S. van Hoof, Innovation in yeast cell filtration: cost saving technology with high flux membranes, Proceedings of the EBC Congress, 501-507 (1997).

[22]. C.J.M. van Rijn, W. Nijdam, M.C. Elwenspoek, High flow rate microsieve for biomedical applications, Proceedings of the ASME Dynamic Systems and Control Division, San Francisco, 995-1000 (1995). 
[23]. S. Zhang, L. Xia, C.H. Kang, G. Xiao, S.M. Ong, Y.C. Toh, H.L. Leo, D. van Noort, S.H. Kan, H.H. Tang, H. Yu, Microfabricated silicon nitride membranes for hepatocyte sandwich culture, Biomaterials, 29, 3993 (2008).

[24]. T. Xu, B. Lu, Y-C. Tai, A. Goldkorn, A cancer detection platform which measures telomerase activity from live circulating tumor cells captured on a microfilter, Cancer Res, 70, 6420 (2010).

[25]. S.B. McKenzie, Hematology: Clinical principles and application, Clinical Laboratory Hematology (Upper Saddle River, NJ: Prentice Hall), (2004).

[26]. D. Braasch, Red cell deformability and capillary blood flow, Physiol. Rev, 51, 67 (1971). 